\title{
METODE PERMAINAN EDUKATIF DALAM PEMBELAJARAN BAHASA ARAB
}

\author{
Asnul Uliyah ${ }^{1}$, Zakiyah Isnawati $^{2}$ \\ ${ }^{1,2}$ Institut Agama Islam Negeri Kudus \\ e-mail: ${ }^{1}$ asnululiyah98@gmail.com, ${ }^{2}$ zakiyahisnawati79@gmail.com
}

DOI: $10.24252 /$ saa.v1i1.9375

\begin{abstract}
Abstrak
Pembaharuan dalam pembelajaran bahasa Arab sangat penting terutama dalam hal metode. Metode yang digunakan harus sesuai dengan peserta didik, agar pembelajaran bahasa Arab dapat berhasil. Artikel ini menjelaskan tentang metode permainan edukatif dalam pembelajaran Bahasa Arab beserta contoh penerapannya yang tujuannya dapat digunakan oleh pendidik sebagai salah satu cara penyampaian materi Bahasa Arab yang tidak lagi monoton dan membosankan melainkan menjadi mudah dan menyenangkan. Data dikumpulkan berdasarkan penelitian pustaka, yaitu dengan mengumpulkan, membaca, dan menganalisa sumber bacaan terkait tema. Dalam artikel ini, pembaca akan diajak penulis untuk berdiskusi terkait dengan pemahaman tentang metode, apa tujuan dan fungsi digunakannya metode terutama pada metode permainan edukatif, kemudian pentingnya penggunaan metode permainan edukatif dan contoh penerapannya dalam pembelajaran Bahasa Arab.
\end{abstract}

Kata Kunci: Metode, Pembelajaran, Bahasa Arab, Permainan Edukatif

\section{PENDAHULUAN}

Pembelajaran bahasa Arab seringkali menjadi salah satu pelajaran yang sangat menakutkan bagi peserta didik di sekolah maupun madrasah. Banyak di antara mereka yang tidak suka ketika mendapatkan pelajaran bahasa Arab. Padahal eksistensi bahasa Arab sangat penting dalam dunia Islam. Namun, peserta didik masih banyak yang tidak suka dengan pelajaran Bahasa Arab. Sehingga, dalam hal ini perlu ada sebuah perubahan dalam pembelajaranya. Salah satunya, metode pembelajaran yang digunakan harus dirubah untuk menumbuhkan ketertarikan peserta didik terhadap pelajaran bahasa Arab. Dan ketika mereka sudah tertarik terhadap pelajaran bahasa Arab, maka tidak langsung mereka akan mampu mengikuti pembelajaran dengan senang hati tanpa ada unsur paksaan dan tekanan. Dengan demikian, proses pembelajaran bahasa Arab akan berlangsung sesuai rencana dan mampu diserap peserta didik dengan mudah dan menyenangkan.

Dalam pembelajaran bahasa asing seperti bahasa Arab, metode mempunyai kedudukan yang sangat penting untuk mencapai tujuan pembelajaran. Selain itu, metode pembelajaran dapat di ibaratkan sebagai suatu pelayanan yang akan di apresiasi oleh peserta didik dan akan membekas dalam hati dan pikiran mereka. Sehingga metode pembelajaran yang baik, kreatif, dan menyenangkan akan lebih membekas dalam diri peserta didik. Seperti halnya metode permainan edukatif yang dapat dijadikan rujukan pendidik sebagai salah satu metode pembelajaran bahasa Arab yang menyenangkan. Karena, pada dasarnya jika semua yang berhubungan dengan permainan maka semua orang akan menyukainya. Hal ini sudah dijelaskan dalam Alqur'an Surat Al-An'am ayat 32 yang artinya “Kehidupan dunia ini 
adalah main-main dan senda gurau belaka dan sungguh kampong akhirat itu lebih baik bagi orang-orang yang bertaqwa. Apakah kau semua tidak memikirnya?

Hal ini yang membuat penulis tertarik dan ingin berusaha mengkaitkan permainan dan pembelajaran agar dapat terciptanya pembelajaran yang mudah serta menyenangkan. Yaitu dengan adanya penerapan metode permainan edukatif dalam pembelajaran bahasa Arab yang kemudian akan memberi suatu pembaharuan dalam mengkonsep sebuah pembelajaran. Karena pada dasarnya sebuah metode dalam pembelajaran sangatlah penting. Mahmud Yunus bahkan mengatakan metode itu lebih penting dari materi. Pernyataan ini perlu mendapat perhatian lebih mengingat banyak anggapan kurang benar yang mengatakan bahwa penguasaan materi adalah segalanya. Penguasaan materi dianggap menjadi jaminan untuk mengajarkan ilmu kepada siapa saja. Namun demikian, kenyataan menunjukkan bahwa seseorang yang cukup pintar dan menguasai suatu ilmu tertentu ternyata sering menemukan semacam batu sandungan dalam mengomunikasikan ilmu tersebut secara efektif. ${ }^{2}$

Pembelajaran Bahasa Arab perlu adanya pembaharuan dengan menggunakan metode pembelajaran edukatif. Sehingga, pendidik tidak hanya menggunakan satu metode saja, namun alangkah baiknya sebagai pendidik dapat menggabungkan beberapa metode dalam pembelajaran Bahasa Arab, karena sejatinya tidak ada metode yang sempurna. Dengan begitu bebrapa metode pembelajaran Bahasa Arab dapat digunakan dan diterapkan kepada peserta didik sesuai dengan karakternya dan disesuaikan pula dengan kondisi maupun keadaan Sehingga dalam artikel ini, penulis ingin memperkenalkan pemahaman terkait metode khusunya metode permainan edukatif dalam pembelajaran Bahasa Arab.

\section{METODE}

Metode penelitian yang digunakan adalah deskriptif kualitatif dengan menggunakan pendekatan pustaka atau riset pustaka dan analisis data. Di mana dalam penelitian ini penulis mendeskripsikan data yang terkumpul dan menganalisisnya berdasarkan content analizing atau analisis isinya terkait dengan metode permainan edukatif dalam pembelajaran bahasa Arab. Dalam riset pustaka, penulis telah mengumpulkan beberapa metode permainan edukatif yang dapat diterapkan dalam pembelajaran bahasa Arab berdasarkan penggolongan dari keempat keterampilan dari bahasa Arab, yaitu dalam kemahiran membaca (qira'ah), kemahiran berbicara (kalam), kemahiran menulis (kitabah), dan kemahiran (istima'). Sedangkan kegunaan penelitian adalah sebagai bahan studi lanjutan yang relevan dan bahan kajian ke arah pengembangan metode pembelajaran bahasa Arab yang efektif dan menyenangkan dengan berbagai contoh penerapan metode permainan edukatif dalam berbagai bentuk dan variasi yang dapat digunakan sebagai salah satu rujukan bagi pendidik dalam melaksanakan pembelajaran bahasa Arab.

\footnotetext{
${ }^{1}$ Imam Asrori, 1000 Permainan Penyegar Pembelajaran Bahasa Arab (Cet IV; Malang: CV. Bintang Sejahtera, 2018), h. 1.

${ }^{2}$ Junanah, "Silent Way: Metode Pembelajaran Bahasa Arab yang Mendorong Peserta Didik Lebih Kreatif, Mandiri, dan Bertanggung Jawab”, El-Tarbawi 7. No. 1 (2014): h. 41
} 


\section{HASIL DAN PEMBAHASAN}

\section{Metode Pembelajaran Bahasa Arab}

Sebelum kita membahas lebih dalam mengenai metode pembelajaran Bahasa Arab, perlu kita ketahui apa itu metode dan pembelajaran yang kemudian kedua kata tersebut menjadi satu kesatuan metode pembelajaran khususnya pada pelajaran bahasa Arab. Ditinjau dari segi etimologis, metode berasal dari bahasa Yunani, yaitu "methodos". Kata ini terdiri dari dua suku kata, yaitu "metha" yang berarti melalui atau melewati, dan "hodos" yang berarti jalan atau cara. Maka metode memiliki arti suatu jalan yang dilalui untuk mencapai tujuan. Dan dalam bahasa Arab kata metode diungkapkan dalam berbagai kata seperti althariqah, al-manhaj, dan al-wasilah, namun antara ketiganya yang paling dekat dengan metode adalah kata al-thariqat yang berarti jalan. ${ }^{3}$

Sedangkan metode dilihat secara harfiah, metode merupakan "cara". Dalam pemakaian yang umum, metode diartikan sebagai cara melakukan suatu kegiatan atau pekerjaan menggunakan fakta dan konsep secara sistematis. Metode juga dapat diartikan sebagai sistematika umum bagi pemilihan, penyusunan, serta penyajian materi kebahasaan. ${ }^{4}$ Metode sebenarnya adalah seperangkat cara yang digunakan oleh seseorang guru dalam menyampaikan ilmu atau transfer ilmu kepada anak didiknya yang berlangsung dalam proses belajar dan mengajar atau proses pembelajaran. Sehingga ketika seorang guru semakin menguasai metode pembelajaran, maka semakin baik pula ia dalam menggunakan metode tersebut. ${ }^{5}$

Dalam pengertian yang lain disebutkan bahwa metode adalah rencana menyeluruh yang berkenaan dengan penyajian materi bahasa secara teratur, tidak ada satu bagian yang bertentangan dengan yang lain dan semuanya berdasarkan atas approach yang telah dipilih. Dan approach itu sendiri di dalam bahasa Arab disebut al-madhal yaitu seperangkat asumsi mengenai hakikat bahasa dan hakikat belajar-mengajar bahasa yang sifatnya aksimatik (filosofis). ${ }^{6}$

Dari beberapa pengertian di atas, dapat disimpulkan bahwa metode sering disebut sebagai cara yang dilakukan oleh pendidik atau guru dalam menyampaikan materi kepada peserta didik dengan tujuan untuk membantu mempermudah dalam proses belajar mengajar. Sedangkan ketika metode itu digabungkan pada pembelajaran Bahasa arab maka kita harus dulu paham apa itu pembelajaran. Kata pembelajaran itu sendiri merupakan interaksi bolakbalik antara dua pihak yang saling membutuhkan, yaitu guru dan murid. Dalam interaksi tersebut, terjadi komunikasi (transfer) yang intens dan terarah menuju target yang telah ditetapkan sebelumnya. ${ }^{7}$ Pembelajaran itu terkait dengan bagaimana membelajarkan siswa atau bagaimana membuat siswa dapat belajar dengan mudah dan dorongan oleh kemauannya

${ }^{3}$ Ismail SM, Strategi Pembelajaran Agama Islam Berbasis PAIKEM (Cet IV; Yogyakarta: Rasail Media Group, 2009), h. 7.

${ }^{4}$ Ismail. SM, Strategi Pembelajaran Agama Islam Berbasis PAIKEM, h. 148.

${ }^{5}$ Ulin Nuha, Ragam Metodologi Dan Media Pembelajaran Bahasa Arab (Yogyakarta: Diva Pres, 2016), h. 147. 19.

${ }^{6}$ Azhar Arsyad, Bahasa Arab dan Metode Pengajaranya (Cet III; Yogyakarta: Pustaka Pelajar, 2010), h.

\footnotetext{
${ }^{7}$ Ulin Nuha, Ragam Metodologi Dan Media Pembelajaran Bahasa Arab, h. 143-144.
} 
sendiri untuk mempelajari apa yang teraktualisasikan dalam kurikulum sebagai kebutuhan peserta didik. ${ }^{8}$

Metode pembelajaran menurut pengertian yang lain merupakan istilah yang berkaitan dengan perencanaan secara menyeluruh untuk menyajikan materi pelajaran secara runtut dan teratur. Metode bersifat prosedural dalam arti penerapan suatu metode dalam pembelajaran dikerjakan dengan langkah-langkah yang teratur dan bertahap dimulai dari penyusunan perencanaan pembelajaran, penyajian bahan pembelajaran, proses belajar mengajar, dan penilaian hasil belajar. ${ }^{9}$ Berdasarkan pembelajaran yang selama ini ada, hendaknya bagi pendidik menggunakan metode secara bergantian atau saling bahu membahu satu sama lain sesuai situasi dan kondisi sebagai bentuk proses pembelajaran yang baik. Metode pembelajaran harus disesuaikan dengan situasi, kondisi, dan karakter siswa agar suasana kelas lebih hidup dan menyenangkan. Dengan begitu dengan berjalannya waktu peserta didik akan tidak sadar senang belajar bahasa Arab tanpa adanya tekanan dan paksaan atau kewajiban.

\section{Tujuan dan Fungsi dari Metode Pembelajaran}

Metode yang dipilih oleh pendidik tidak boleh bertentangan dengan tujuan pembelajaran. Pembelajaran merupakan proses interaksi peserta didik dengan pendidik dan sumber belajar pada suatu lingkungan belajar. Dengan kata lain pembelajaran adalah proses untuk membantu peserta didik agar dapat belajar dengan baik. ${ }^{10}$ Begitu pula dengan metode pengajaran bahasa, termasuk bahasa Arab, berkembang dari masa ke masa seiring dengan perkembangan teori-teori yang melandasinya, hasil-hasil penelitian dan eksperimentasi dalam pengajaran bahasa, di samping perkembangan tunt utan masyarakat di bidang bahasa. ${ }^{11}$

Metode harus mendukung arah kemana kegiatan interaksi edukatif berproses guna mencapai tujuan. Metode bertujuan untuk lebih memudahkan proses dan hasil pembelajaran sehingga apa yang telah direncanakan bisa diraih dengan sebaik dan semudah mungkin. Dengan demikian, jelas bahwa metode sangat berfungsi dalam penyampaian materi pembelajaran. Dalam kegiatan pembelajaran, pastilah metode sangat penting dan diperlukan oleh setiap guru dan penggunaanya juga bermacam-macam sesuai dengan tujuan yang ingin dicapai setelah kegiatan pembelajaran selesai dilaksanakan. Karena itu, metode dalam pembelajaran mempunyai fungsi yang terbagi menjadi beberapa bagian, di antaranya yaitu sebagai berikut: ${ }^{12}$

a. Metode sebagai alat motivasi ekstrinsik

b. Metode sebagai strategi pengajaran

c. Metode sebagai alat untuk mencapai tujuan

Tujuan adalah inti dari setiap kegiatan pembelajaran. Dalam rangka mencapai tujuan pembelajaran ini, pasti guru sering kali melakukan dan mengembangkan inovasi dari

\footnotetext{
${ }^{8}$ Ismail. SM, Strategi Pembelajaran Agama Islam Berbasis PAIKEM, h. 10.

${ }^{9}$ Andayani, Problema dan Aksioma: dalam Metodologi Pembelajaran Bahasa Indonesia (Yogyakarta: Dee publish, 2015), h. 84.

${ }^{10}$ M. Khalilulloh, Media Pembelajaran Bahasa Arab, (Yogyakarta: Aswaja Pressindo, 2009), h. 3.

${ }^{11}$ Ahmad Fuad Effendy, Metodologi Pengajaran Bahasa Arab (Cet VII; Malang: Misykat, 2017), h. 8.

${ }^{12}$ Ulin Nuha, Metodologi Super Efektif Pembelajaran Bahasa Arab (Yogjakarta: Diva Press, 2012), h.
} $160-162$ 
kegiatan belajar dan mengajar. Salah satu usaha yang dilakukan guru tersebut adalah mengembangkan metode pembelajaran yang digunakan. Hal ini karena metode adalah salah satu alat untuk mencapai sebuah tujuan pembelajaran. Oleh karena itu, wajib bagi guru untuk menggunakan dan menerapkan metode dalam pembelajaran. Sehingga metode tersebut dapat dijadikan sebagai sebuah alat untuk mencapai tujuan pembelajaran. Namun, sebuah metode pembelajaran bahasa Arab akan dianggap sukses dalam aplikasinya apabila mampu memenuhi beberapa hal yang menjadi syarat kesuksesan sebuah metode. Syarat-syarat itu di istilahkan dengan dasar-dasar kesuksesan sebuah metode, diantaranya: ${ }^{13}$

1. Metode itu harus sesuai dengan kondisi peserta didik, tingkat pertumbuhan akalnya, aspek sosialnya, aspek ekonominya dan lingkungan keluarga tempat ia tinggal

2. Metode itu harus mengikuti kaidah-kaidah umum yang dapat digunakan oleh seorang guru sebagai pembimbing dan petunujuk dalam menyelesaikan problematika pembelajaran.

3. Harus mampu mengakomodir perbedaan pribadi peserta didik di kelas, baik mempunyai kemampuan yang berbeda, kecerdasan yang berbeda, perilaku yang berbeda, dan sebagainya. Sehingga seorang guru bahasa Arab harus mampu mengurai perbedaan-perbedaan pribadi peserta didik itu dan mengatasinya.

\section{Metode Permainan Edukatif Bahasa Arab}

Istilah permainan, menurut pengertiannya adalah situasi atau kondisi tertentu saat seseorang mencari kesenangan atau kepuasan melalui suatu aktivitas atau kegiatan bermain. Permainan merupakan suatu aktivitas yang bertujuan memperoleh kemahiran tertentu dengan cara menggembirakan seseorang. Permainan merupakan sarana yang efektif dan efisien serta penting untuk menghibur, mendidik, memberikan dampak positif, dan membesarkan setiap pribadi. Parten, dalam Dockett dan Fleer, memandang kegiatan bermain sebagai sarana sosialisasi. Melalui bermain, diharapkan dapat memberikan kesempatan kepada peserta didik dalam bereksplorasi, berkreasi dan belajar secara menyenangkan. ${ }^{14}$

Setelah kita mengetahui penjelasan mengenai permainan, kemudian kita akan mengaitkan permainan yang edukatif pada pembelajaran bahasa Arab. Permainan edukatif adalah permainan yang memiliki unsur mendidik yang didapatkan dari sesuatu yang ada dan melekat serta menjadi bagian dari permainan itu sendiri. ${ }^{15}$ Namun, dalam pembahasan ini kita fokuskan hanya pada permainan bahasa yang edukatif. Permainan bahasa itu sendiri merupakan cara mempelajari bahasa melalui permainan. Suatu kegiatan dapat disebut permainan bahasa apabila suatu aktivitas tersebut mengandung unsur kesenangan dan melatih keterampilan berbahasa atau unsur bahasa tertentu.

Dengan demikian, permainan edukatif pembelajaran Bahasa Arab merupakan suatu metode pembelajaran yang di mana akan memberikan rangsangan kepada peserta didik dan tidak langsung sifat ketidaksukaannya terhadap pelajaran Bahasa Arab akan sedikit berangsur menjadi suka seiring dengan pembelajaran yang dilakukan dengan menyenangkan.

\footnotetext{
${ }^{13}$ Fathur Rohman, Metodologi Pembelajaran Bahasa Arab (Malang: Madani : Kelompok Intrans Publishing, 2015), h. 132.

${ }^{14}$ Fathul Mujib dan Nailur Rahmawati, Metode Permainan-Permainan Edukatif dalam Belajar Bahasa Arab (Jogjakarta:Diva Press, 2011), h. 26-27.

${ }^{15}$ Fathul Mujib dan Nailur Rahmawati, Metode Permainan-Permainan Edukatif dalam Belajar Bahasa Arab, h. 29.
} 
Karenanya, ketika peserta didik terlibat dalam permainan secara serius sifat sukarela dan motivasi dating dari dalam diri peserta didik sendiri secara spontan.

\section{Pentingnya Permainan dalam Pembelajaran}

Pembelajaran memang tidak selalu membutuhkan permainan, dan permainan sendiri tidak selalu dalam rangka mempercepat proses pembelajaran. Akan tetapi, permainan yang dimanfaatkan dengan bijaksana dapat menambah variasi, semangat, dan minat pada sebagian proses belajar mengajar. Seringkali guru mengeluh karena banyak siswa yang kemampuan belajarnya masih rendah terutama dalam belajar berbahasa, meskipun guru sudah berupaya menggunakan berbagai model atau metode pembelajaran. Penerapan permainan bahasa merupakan salah satu alternatif untuk meningkatkan kemampuan peserta didik dalam belajar bahasa Arab.

Permainan merupakan bagian yang sangat penting dalam kehidupan manusia. Dalam kehidupan sehari-hari tampak bahwa setiap orang, laki-laki dan perempuan, anak-anak dan dewasa, kaya dan miskin, semuanya menyenangi permainan. ${ }^{16}$ Dengan demikian, semua yang terkait dengan permainan maka akan disenangi banyak orang, karena pada dasarnya setiap manusia memang senang pada permainan. Termasuk juga pada pembelajaran bahasa Arab yang kemudian akan menyenangkan dan disenangi oleh para peserta didik. Permainan dalam belajar jika dimanfaatkan secara baik dan benar dapat menghasilkan beberapa hal berikut: ${ }^{17}$

a. Menyingkirkan "keseriusan" yang menghambat proses belajar

b. Menghilanhkan stres dalam lingkungan belajar

c. Mengajak siswa terlibat secara penuh

d. Meningkatkan proses belajar

e. Membangun kreatvitas diri

f. Mencapai tujuan dengan ketidaksadaran,

g. Meraih makna belajar melalui penglaman

h. Memfokuskan siswa sebagai subjek belajar

Selain itu permainan sangat bermanfaat apabila dapat kita terapkan dengan tepat. Misalnya kita kaitkan antara permainan dengan metode pembelajaran yang diterapkan di sekolah maupun di madrasah. Hal ini dikarenakan, sebuah permainan merupakan proses untuk keahlian anak selanjutnya pada suatu praktik untuk kemudian hari. Permainan sangat penting untuk perkembangan kemampuan kecerdasan. Dengan permainan, anak-anak dapat bereksperimen tanpa gangguan sehingga dengan adanya sebuah permainan, mereka akan mampu membangun kemampuan yang kompleks. Permainan merupakan cara atau jalan bagi anak untuk mengungkapkan hasil pemikiran, perasaan, serta cara mereka menjelaskan dunia lingkungannya, bermain juga membantu anak dalam menjalin hubungan sosial. Dengan demikian anak membutuhkan waktu yang cukup untuk bermain, seperti pada saat mereka bermain di sekolah dapat membantu perkembangan anak apabila guru cukup memberikan waktu, ruang, materi dan kegiatan bermain anak.

Dalam permainan bahasa yang diintregrasikan dalam pengajaran seharusnya mempunyai beberapa tujuan, yaitu sebagai berikut:

\footnotetext{
${ }^{16}$ Imam Asrori, 1000 Permainan Penyegar Pembelajaran Bahasa Arab, h. 2.

${ }^{17}$ Fathul Mujib dan Nailur Rahmawati, Metode Permainan-Permainan Edukatif Dalam Belajar Bahasa Arab, h. 36.
} 
a. Merangsang interaksi verbal siswa

b. Menambah kefasihan dan kepercayaan diri siswa

c. Menyediakan konteks pembelajaran

d. Alat mengikis rasa bosan

e. Sebagai alat pemulihan, pengukuhan, dan pengayaan ${ }^{18}$

Berdasarkan beberapa tujuan di atas, dapat kita ketahui bahwa permainan edukatif yang diterapkan pada pembelajaran bahasa Arab akan membuat suatu kondisi yang di mana kondisi tersebut berpengaruh kepada diri peserta didik. Misalnya dapat mengikis kebosanan, memang banyak di antara mereka peserta didik merasa bosan dengan pelajaran bahasa Arab karena metode atau cara pembelajaran yang masih monoton. Hal ini bisa diatasi dengan adanya pemilihan metode permainan bahasa edukatif yang menyenangkan dan mampu mengikis kebosanan dari peserta didik dalam mempelajari Bahasa Arab.

Tidak hanya itu, ketika kita berhadapan pada permainan ini justru kita dapat menimbulkan perasaan gembira pada diri peserta didik dan menyebabkan mereka menjadi lupa akan keluhan yang sedang mereka alami, dari rasa mengantuk, perasaan lesu atau yang lainnya. Oleh karenanya, sebagai seorang pendidik perlu memperhatikan karakter dan kondisi peserta didiknya yang masih saja tidak minat atau belum senang dengan pelajaran bahasa Arab. Hal ini bisa diatasi dengan adanya inovasi metode pembelajaran yang mampu membuat peserta didik suka dan minat kembali atau bahkan ketagihan untuk belajar Bahasa Arab. Agar apa yang menjadi tujuan pembelajaran Bahasa Arab bisa tercapai sesuai dengan apa yang telah direncanakan.

\section{Beberapa Contoh Permainan Edukatif dalam Pembelajaran Bahasa Arab}

Unsur ketrampilan berbahasa terdiri dari empat macam, yaitu: istima', kalam, qiro'ah, dan kitabah. Dalam rangka pembelajaran dan penempaan keempat macam ketrampilan tersebut, terdapat aneka ragam permainan bahasa edukatif yang bisa digunakan sebagai media pembelajarannya. Secara garis besar, ada empat kelompok permainan bahasa yang akan dibahas. Pertama, permainan membaca. Kedua, permainan berbicara. Ketiga, permainan menulis. Keempat, permainan mendengar.

a. Permainan Kemahiran Membaca (Qira'ah)

Ada beberapa permainan yang bisa diterapkan dalam pembelajaran bahasa Arab pada maharotul qira'ah antara lain:

1) Siapa Dia ${ }^{19}$

Permainan ini bertujuan melatih membaca dan bernalar. Peralatan yang digunakan adalah kartu kata. Sebelumnya guru menyiapkan dua macam kartu yang bertuliskan jenis profesi dan kerja sesuai dengan jenis profesi tersebut. Dalam variasi yang guru dapat mengganti kartu dengan tema berbeda seperti nama-nama binatang atau sesuatu yang lain, dan guru tetap memegang kartu tentang tempat. Adapun cara bermainnya, yaitu:

\footnotetext{
${ }^{18}$ Fathul Mujib dan Nailur Rahmawati, Metode Permainan-Permainan Edukatif Dalam Belajar Bahasa Arab, h. 40-44.

${ }^{19}$ Imam Asrori, 1000 Permainan Penyegar Pembelajaran Bahasa Arab, h.77-78.
} 
a) Siswa dibagikan kartu jenis profesi dan mereka diminta membaca dan diperlihatkan kartu yang bertuliskan tempat kerja dan disuruh membacanya juga

b) Guru menanyakan orang yang bekerja di tempat itu

c) Siswa membawa kartu yang bertuliskan sama dengan yang ditanyakan guru sambil mengangkat tangan dan membaca kartunya

d) Jika jawaban sudah benar, maka guru menyuruh siswa membuat kalimat terkait jenis profesi beserta tempat kerjanya

b. Kata Berjajar

Permainan ini bertujuan melatih membaca. Hal yang harus dipersiapkan oleh guru adalah, pertama guru menyiapkan kartu bertuliskan nama siswa, nama atau jenis binatang, keterangan tempat, kata kerja berkala kini (fi'il mudhari') untuk orang ketiga berdua dan salah satu bertuliskan "wawu 'athaf". Ukuran kertas dibuat dengan ukuran $15 \times 20 \mathrm{~cm}$. dan guru membagi kelas menjadi 4 kelompok. Adapun cara bermainnya, yaitu:

1) Guru membagikan kartu "a" kepada kelompok 1, kartu "b" kepada kelompok 2 begitu seterusnya. Sedangkan kartu yang bertuliskan "wawu 'athaf" dipegang oleh guru

2) Guru meminta setiap anggota kelompok untuk membaca dengan keras setiap kartunya secara berurutan

3) Salah satu siswa dari setiap kelompok diminta maju berjajar memperlihatkan kartunya dengan urutan kelompok

4) Guru mengambil tempat di antara anggota kelompok 1 dan 2 serta memperlihatkan kartunya seperti yang dilakukan oleh yang lain

5) Salah satu atau dua siswa yang tidak ikut maju diminta membaca kalimat dalam kartu yang berjajar

6) Guru meminta kelas membahas maknanya karena ada kemungkinan dalam pembacaannya yang salah juga akan menimbulkan arti yang berbeda. Dan selanjutnya permainan dilanjutkan sampai kartu terakhir

c. Tusuk Kata ${ }^{20}$

Permainan ini bertujuan agar siswa dapat mengelompokkan jenis kata dan menambah perbendaharaan kata. Permainan ini cocok untuk mengajarkan identifikasi dan pengelompokkan. Misalnya, identifikasi macam-macam kalimat, ciri-ciri kalimat, membedakan huruf jar, jazm, dan lain sebagainya. Alat yang diperlukan dalam permainan adalah lidi dan kertas. Bentuk dari kertas ini seperti lingkaran-lingkaran kecil yang bertuliskan kosa kata Arab. Cara bermain dari permainan ini adalah sebagai berikut:

1) Guru membuat lingkaran-lingkaran kecil seperti daging dari kertas manila.

2) Guru membagi siswa menjadi beberapa kelompok.

3) Guru memberikan instruksi tentang mekanisme tusuk kata (pemainan tusuk kata) kepada masing-masing kelompok.

4) Masing-masing kelompok mencari dan mengumpulkan kelompok yang telah diacak dan menyusunnya dengan menusukkan kata (sejenis) yang sesuai dengan kelompok kata tersebut.

${ }^{20}$ Fathul Mujib dan Nailur Rahmawati, Metode Permainan-Permainan Edukatif Dalam Belajar Bahasa Arab, h. 85-87. 
5) Siswa mencari, mendiskusikan, dan mengklasifikasi kata sesuai dengan bagiannya masing-masing.

6) Setelah game selesai, tiap kelompok mengirim perwakilan untuk mempresentasikan hasil diskusinya.

\section{d. Strip Story (Potongan Kertas) ${ }^{21}$}

Tujuan dari permainan ini adalah membantu kemampuan siswa dalam mengurutkan kalimat secara tepat dan benar. Teknik lewat media ini bertitik tolak dari suatu approach yang menggunkan aktivitas komunikasi yang sesungguhnya agar kelak siswa dapat dengan mudah dan tidak sungkan untuk berkomunikasi dengan bahasa asing. Berikut secara detail cara penggunaan dan pembuatan permainan strip story:

1) Sebelum masuk kelas

a) Guru memilih suatu topik cerita dalam muthola'ah atau mahfuzhah yang kira-kira dapat dibagi rata kalimat-kalimatnya kepada siswa.

b) Kalimat-kalimat tersebut ditulis atau diketik dengan jelas dengan mengosongkan ruang ekstra antara setiap kalimat dengan kalimat.

c) Lembaran kisah tersebut dipotong-potong dengan gunting menjadi berkeping-keping dengan satu kalimat untuk satu kepingan/potongan.

2) Dalam kelas

a) Kepingan-kepingan kertas yang berisi kalimat-kalimat itu dibagi-bagikan secara random kepada siswa.

b) Guru meminta siswa menghafal luar kepala kalimatnya dalam sekejap (satudua menit). Siswa-siswa dilarang menulis apa-apa atau memperlihatkan kalimatnya kepada orang lain.

c) Guru meminta murid untuk mengumpulkan kembali strip tersebut

d) Guru meminta para siswa untuk berdiri dari kursi. Kalau kelas besar atau murid banyak, mereka dibagi per grup.

e) Siswa sibuk berusaha menyusun cerita

f) Setelah kalimat itu teratur rapi dalam bentuk sebuah cerita dan mereka setuju, mereka lalu berdiam diri.

g) Setiap individu menyebut kalimatnya secara berturut sehingga berbentuk satu cerita yang teratur.

h) Kalau waktu masih mengizinkan, murid-murid bisa diminta untuk menulis kisah tersebut dalam buku mereka dan mereka saling mendiktekan kalimat mereka dengan temannya.

i) Setelah semua dilakukan oleh murid, teks asli cerita tersebut dibagikan atau diperlihatkan melalui overhead projector.

Dari permainan di atas, dapat kita ketahui bahwa median potongan-potongan kertas stir story bisa dipakai untuk mata pelajaran: imla', muhadatsah, muthola'ah, mahfuzhah, dan insya'. Dengan demikian, permainan stir story bisa digunakan dalam pembelajaran kemahiran menulis (maharatul kitabah).

${ }^{21}$ Fathul Mujib dan Nailur Rahmawati, Metode Permainan-Permainan Edukatif Dalam Belajar Bahasa Arab, h. 118-119. 


\section{Permainan Kemahiran Berbicara (Kalam)}

Permainan bahasa edukatif yang berkaitan dengan ketrampilan berbicara antara lain:

a. Pelayan Kantin

Tujuan dari permainan ini adalah untuk mengembangkan keterampilan berbicara dalam tema menggunakan ungkapan jual-beli. Perlengkapannya cukup segala model perlengkapan yang berhubungan dengan kantin. Cara bermainnya, yaitu:

1. Kelas dibagi menjadi kelompok a (seorang siswa menjadi pelayan kantin) dan $b$ (tiga siswa menjadi pelanggan)

2. Guru/siswa menyiapkan potongan kertas untuk ditulisi nama-nama makanan yang dijual

3. Guru menjelaskan apa yang harus dilakukan masing-masing pemeran, dan menjelaskan beberapa istilah yang berkaitan dengan layanan kantin dan menunya sebagaimana dalam kotak

4. Semua berperan masing-masing sesuai tugasnya sehingga akan terjadi interaksi jual-beli atau komunikasi antara pelayan dan pelanggan dengan menggunakan bahasa Arab yang sudah diberikan teks bacaan maupun percakapan mengenai jualbeli.

b. Ular Tangga ${ }^{22}$

Permainan bahasa ular tangga adalah permainan yang menggunakan media papan atau kertas ular tangga. Tujuan dari permainan ini adalah melatih kecepatan siswa dalam berbicara. Beberapa alat yang diperlukan dalam permainan ini yaitu: papan, kertas ular tangga yang dilengkapi gambar, dan dadu. Dadu tidak harus seperti dadu umumnya, guru bisa membuat dadu sendiri dengan angka Arab. Dan adapun cara bermainya, yaitu:

1. Guru menyiapkan media ular tangga (guru bisa membuat istilah sendiri)

2. Guru membagi siswa menjadi beberapa kelompok

3. Aturan main sama persis seperti permainan ular tangga pada umumnya. Ketika siswa berhenti pada satu kotak, maka ia harus berbicara apa saja yang berhubungan dengan sesuatu di kotak tersebut.

\section{c. Terka aksi}

Permainan ini bertujuan melatih kecermatan dan kreativitas siswa. alat yang dibutuhkan dalam permainan ini hanya kartu aksi. Dan cara bermainya, yaitu: guru membagikan kartu aksi kepada masing-masing kelompok. Satu kelompok bisa terdiri atas dua orang atau lebih. Salah satu siswa bertugas menjadi peraga dari kartu aksi tersebut. Dia harus melakukan gerakan (berupa aktivitas atau aksi) sesuai dengan kartu yang dipegangnya. Sedangkan siswa yang lain menebak gerakan tersebut.

Guru atau siswa mempraktikkan aksi tersebut layaknya pemain antonim. Ia hanya boleh bergerak menyerupai aksi tertentu, tetapi tidak boleh menyebutkan nama aksinya menggunakan suara. Permainan ini dapat dilakukan dengan bergantian dari siswa yang telah dibagi menjadi beberapa kelompok.

${ }^{22}$ Fathul Mujib dan Nailur Rahmawati, Metode Permainan-Permainan Edukatif Dalam Belajar Bahasa Arab, h. 127-129. 


\section{d. Cerita Berantai}

Cerita berntai merupakan permainan yang bertujuan melatih kecermatan, kreativitas, dan kecepatan siswa. alat yang harus dipersiapkan dalam permainan ini berupa buku bacaan atau materi yang akan dijadikan bacaan acuan bagi guru. Dan cara bermainya, yaitu: siswa dibagi menjadi beberapa kelompok atau individual. Guru memulai cerita, lalu menunjuk siswa atau kelompok untuk meneruskan cerita. Setiap individu atau kelompok harus memperhatikan apapun yang diucapkan oleh kelopok lainnya. Sebab guru dapat menunjuk siapapun untuk meneruskan cerita. Jangan lupa, guru harus memberi batas waktu kepada siswa atau kelompok untuk berpikir dalam waktu yang ditentukan.

\section{Permainan Kemahiran Menulis (Kitabah)}

Permainan edukatif yang terkait dengan ketrampilan menulis antara lain:

a. Menggandeng Huruf

Permainan ini bertujuan agar siswa mengenal abjad dan melatih mereka menggandeng huruf huruf hijaiyah. Beberapa alat yang diperlukan antara lain kertas, bolpoin, dan buku iqra' sebagai alat peraga. Adapun cara bermain dari permainan ini, yaitu:

1. Guru menyediakan gambar sebagai kata kunci, dan potongan kalimat

2. Guru membagi selembar kertas kepada masing-masing siswa yang berisi gambar sebagai kata kunci, dan beberapa potongan kalimat ayang disertai terjemahannya. Siswa menggandeng kalimat yang terpotong itu menjadi susunan yang benar.

\section{b. Menulis Kalimat Terpanjang ${ }^{23}$}

Permainan ini bertujuan agar siswa berlatih memikirkan kata-kata yang tepat dan merangkainya dalam urutan logis berdasarkan tata bahasa yang benar dan tepat. Alat-alat yang diperlukan dalam permainan ini antara lain: pulpen atau spidol dan kertas. Permainan ini bisa dimainkan secara individu atau kelompok. Dan cara bermainya, yaitu:

1. Guru membuat beberapa kelompok.

2. Setiap kelompok berdiri sejajar atau berbaris. Tiap barisan diberi satu kertas dan pulpen atau spidol.

3. Setiap barisan harus membuat kalimat yang berarti. Setiap barisan hanya boleh menuliskan satu kata dan dilakukan secara berurutan dimulai dari peserta paling ujung yang satu sampai ujung yang lain.

4. Jika kalimat belum selesai sampai pada orang yang terakhir, maka diulang lagi sampai kepada orang yang pertama, sampai kalimat berhenti dan benar.

\section{Permainan Kemahiran Menyimak (Istima')}

Di antara permainan edukatif yang bisa digunakan pendidik pada pembelajaran ketrampilan istima'yaitu:

a. Kursi Bernomor ${ }^{24}$

Tujuan dari permainan kursi bernomor ini adalah mengembangkan kemampuan menyimak. Cara bermainnya yaitu misalnya ada 12 siswa dalam permainan, salah

\footnotetext{
${ }^{23}$ Fathul Mujib dan Nailur Rahmawati. Metode Permainan-Permainan Edukatif Dalam Belajar Bahasa Arab, h. 198-199.

${ }^{24}$ Imam Asrori, 1000 Permainan Penyegar Pembelajaran Bahasa Arab, h. 17-18.
} 
seorang siswa mengucapkan nomor tertentu dari 1 sampai 12 dengan bahasa Arab. Misalnya ia mengucapkan angka 7 ( $\left.S a b^{\prime} a h\right)$, maka siswa yang kebetulan duduk di kursi nomor 7, harus segera mengucapkan nomor yang lain dalam rentang 1-12, misalnya no 5 (Khomsah). Begitu seterusnya. Jika siswa menyebutkan nomornya sendiri atau jika ia lama tidak mengucapkan nomor yang lain, maka ia harus pindah ke kursi yang paling akhir. Dengan demikian, semua siswa yang berada di sebelah kanan siswa tersebut ikut bergeser satu kursi ke kiri.

\section{b. Bisik Kata}

Permainan ini dinamakan bisik berantai karena setiap pemain secara berurutan harus membisikkan suatu kalimat kepada pemain berikutnya. Kalimat yang dibisikkan adalah kalimat hasil menyimak bisikan pemain sebelumnya. Materi yang dikomunikasikan disesuaikan dengan taraf perkembangan peserta didik. Pola kalimat yang dibisikkan hendaknya sejalan dengan pola kalimat yang diajarkan, dan bukan pola kalimat yang sudah dihafal peserta didik.

Dari beberapa metode permainan yang telah diuraikan di atas, merupakan sebagian contoh saja mengenai metode permainan edukatif dalam pembelajaran bahasa Arab. Namun yang perlu kita ingat bahwasanya setiap dari permainan bisa kita ganti dengan konsep atau materi yang berbeda sesuai dengan tema maupun kebutuhan peserta didik. Bisa saja materi yang diajarkan adalah tingkatan dasar, menengah, atau lanjut maka wajib bagi seorang pendidik mengganti atau merubah materi yaitu dengan memberi materi yang sesuai dengan ketentuan dan tingkatan peserta didik dengan konsep metode permainan edukatif dalam pembelajaran yang ada, khususnya pada pembelajaran yang merujuk pada keempat kemahiran dalam bahasa Arab seperti pada kemahiran berbicara (kalam), kemahiran membaca (qira'ah), kemahiran mendengar (istima'), dan kemahiran menulis (kitabah).

\section{KESIMPULAN}

Dari pembahasan di atas dapat disimpulkan bahwa dalam proses pembelajaran atau belajar mengajar perlu adanya metode terutama bagi seorang pendidik harus mampu memilih dan menggunakan metode yang tepat dalam proses berlangsungnya penyampaian materi agar pembelajaran bahasa Arab dapat tersampaikan dengan baik. Karena sebuah metode sering disebut sebagai cara yang dilakukan oleh pendidik dalam menyampaikan materi kepada peserta didik dengan tujuan untuk membantu mempermudah dalam proses belajar mengajar. Sehingga dengan adanya sebuah metode yang tepat maka pembelajaran yang berlangsung tentu akan berjalan sesuai rencana dan tujuan awal dari sebuah pembelajaran tersebut. Salah satunya yaitu dengan menggunakan metode permainan edukatif bahasa Arab yang dapat diterapkan pada keempat kemahiran bahasa Arab, baik kemahiran berbicara (kalam), kemahiran membaca (qira'ah), kemahiran mendengar (istima'), dan kemahiran menulis (kitabah). Seperti yang telah dipaparkan di atas mengenai beberapa contoh metode permainan edukatif yang dapat dijadikan sebuah rujukan oleh setiap pendidik dalam mengkonsep pembelajaran bahasa Arab. Dengan adanya metode ini diharapkan peserta didik tidak lagi merasa bosan dengan pembelajaran Bahasa Arab. Justru mereka akan merasa senang dengan adanya penerapan metode permainan edukatif ini pada pembelajaran Bahasa Arab. Sehingga, kedepanya nanti pelajaran bahasa Arab akan menjadi salah satu pelajaran di sekolah maupun madrasah yang sangat diminati oleh peserta didik, karena pelajaran bahasa Arab menjadi salah satu pelajaran yang mudah dan menyenangkan. 


\section{DAFTAR REFERENSI}

Andayani. 2015. Problema dan Aksioma: dalam Metodologi Pembelajaran Bahasa Indonesia. Yogyakarta: Dee publish.

Arsyad, Azhar. 2010. Bahasa Arab dan Metode Pengajaranya. Cet III; Yogyakarta: Pustaka Pelajar.

Asrori, Imam. 2018. 1000 Permainan Penyegar Pembelajaran Bahasa Arab. Cet IV; Malang: CV. Bintang Sejahtera.

Fuad Effendy, Ahmad. 2017. Metodologi Pengajaran Bahasa Arab. Cet VII; Malang: Misykat.

Junanah. "Silent Way. Metode Pembelajaran Bahasa Arab yang Mendorong Peserta Didik Lebih Kreatif, Mandiri, dan Bertanggung Jawab". El-Tarbawi 7. No. 1 (2014): h. 41-50.

Khalilulloh, M. 2009. Media Pembelajaran Bahasa Arab, Yogyakarta: Aswaja Pressindo.

Nailur Rahmawati, Fathul Mujib dan. 2011. Metode Permainan-Permainan Edukatif Dalam Belajar Bahasa Arab. Yogjakarta: Diva Press.

Nuha, Ulin. 2012. Metodologi Super Efektif Pembelajaran Bahasa Arab. Yogjakarta: Diva Press.

Nuha, Ulin. 2016. Ragam Metodologi Dan Media Pembelajaran Bahasa Arab. Yogyakarta: Diva Pres.

Rohman, Fathur. 2015. Metodologi Pembelajaran Bahasa Arab. Malang: Madani : Kelompok Intrans Publishing.

SM, Ismail. 2009. Strategi Pembelajaran Agama Islam Berbasis PAIKEM. Yogyakarta: Rasail Media Group. 